\title{
MEU TIO
}

SílVIA RUBIÃO

Sobrinha de Murilo Rubião e herdeira dos direitos sobre sua obra.
"Fui à festa no castelo e trouxe uns docinhos pra você. Mas na volta, escorreguei na careca do tio Murilo e tudo caiu no chão". Assim, minha mãe, uma talentosa contadora de histórias, encerrava os contos de fadas, depois que o príncipe resgatava a princesa em seu cavalo branco e a pedia em casamento. Durante algum tempo esse tio de cabeça luzidia e fartos bigodes povoou minha infância como uma figura mais imaginária do que real.

Nessa época, em meados dos anos 1950, ele morava em Madri, na Espanha, e só se materializaria diante de meus olhos duas ou três vezes, de chapéu e sobretudo, ao desembarcar no Aeroporto da Pampulha. Ali começava a festa, que prosseguia com a mala aberta diante da família reunida, na sala de nossa casa. Tal qual o mágico de sua cartola, o misterioso careca ia retirando mantilhas, leques, castanholas, adereços de toureiros e lindas bonecas espanholas.

Já restabelecido em Belo Horizonte, passamos a ter uma convivência real e mais frequente. Aos sábados, vinha sempre almoçar conosco. Era quando minha mãe caprichava no pão de queijo e na costelinha com canjiquinha, suas iguarias prediletas. Era muito ligado ao meu pai, o médico Paulo Emílio, seu único irmão, um ano mais moço. Introspectivos e de poucas palavras, pareciam-se na personalidade, embora opostos no estilo de vida.

Meu tio, como se sabe, nunca se casou. Não foi por falta de candidatas e pressões 
familiares. Suas relações com as mulheres, algumas breves, outras longas e intermitentes, alimentavam o folclore em torno de sua figura enigmática, envolvendo até uma afamada atriz. Quando minha avó e tias começavam a se alvoroçar com algum namoro mais explícito, elas desapareciam. Ele dizia que era melhor ser solteiro, para "errar sozinho", revelando, também aí, o grande leitor de Machado de Assis que era. Na verdade, cultuava bastante sua independência e a liberdade das noites de boemia. Em nada o inspirava o modelo "pai de numerosa prole" de seu irmão, cujas incursões na madrugada restringiam-se a estudos de casos, aulas a preparar e contas a pagar. Diferenças à parte, eram o esteio um do outro. Encontravam-se sempre, fosse para ouvir no rádio jogos de futebol, irem ao sítio em Itaúna ou para juntos se desesperarem diante das coisas práticas da vida para as quais definitivamente não eram talhados. Declarar Imposto de Renda anualmente era uma delas.

Durante muitos anos, achei que meu tio trabalhava na Gruta Metrópole, o lendário bar da Rua da Bahia. Às vezes quando era levada ao centro da cidade por algum motivo, minha mãe me deixava no consultório do meu pai, na Praça Sete, para voltar com ele. Era quando, a caminho de casa, ele me propunha dar uma paradinha na Gruta "para ver o tio Murilo". No mais só me lembro do falatório enfumaçado, dos pastéis deliciosos e dos apertos na bochecha.

Cresci e nos aproximamos mais, tanto quanto dois tímidos são capazes. Ele percebia meu interesse por histórias e me estimulava. Aprendi a ler sozinha num alfabeto de brinquedo dado por ele, quando uma grave nefrite me deixou acamada por um longo tempo. Elogiava minhas redações e me dava livros (não emprestava, 
nunca, para ninguém!). O primeiro Monteiro Lobato foi ele quem me deu: Viagem ao Céu. $\mathrm{E}$ quase todos os outros. Viajar com os olhos por sua biblioteca toda encadernada em capas coloridas era um imenso prazer, assim como batucar nas teclas de sua máquina de escrever. Sei que o frustrei ao não honrar a tradição familiar e me tornar escritora, como também o foram meu avô, Eugênio Rubião, o primo Godofredo Rangel, entre outros. Certamente lamentava ver a literatura perder espaço na vida da adolescente mais interessada em namorar e curtir bandas de rock. Já adulta, para seu entusiasmo, ganhei concursos de contos e poemas, mas logo me retraí, perdida entre o ganhar a vida e o cuidar de fraldas e mamadeiras.

Nessa época, final da década de 1970, fomos vizinhos de porta num prédio na Serra, na Rua do Ouro. Com três filhos pequenos e trabalhando, pouco pude aproveitar da privilegiada convivência e das noitadas em seu apartamento, onde, pelo menos uma vez por semana, variados grupos de amigos, artistas e intelectuais, rompiam a madrugada em torno de garrafas de uísque.

Por trás da sisudez, de uma discreta gagueira e da economia de gestos, revelava-se um homem extremamente cordial, bom ouvinte, generoso e com sarcástico senso de humor. Tinha um jeito afetuoso de por as mãos nos ombros do interlocutor, coçar o queixo e perguntar com interesse como ia a vida. Era um ser gregário, sempre atraindo pessoas à sua volta. Sua solidariedade não escolhia hora, lugar, nem pessoas. Ninguém saía de sua casa sem ganhar alguma coisa. O bolso cheio de balas para as crianças; sempre uma palavra atenta, para porteiros, motoristas, secretárias, que o adoravam. 
Vivia rodeado por jovens. Nas festas de família, evitava os mais velhos que, segundo ele, "só falavam de doença". Logo se tornou guru e mentor de toda uma geração, que gravitava ao seu redor fosse em sua casa, na redação do Suplemento Literário ou nos bares do Maletta. Atendia a todos, lia e relia originais, corrigia, indicava leituras, encorajava. Muitos deles são hoje escritores e artistas consagrados. Quando começou a ter notoriedade, ia com frequência às universidades, recebia grupos de estudantes, dava entrevistas. Via entusiasmado seus contos serem adaptados para teatro e cinema. Assim, o jeito comedido, a figura reservada, sempre de paletó e piteira nas mãos, escondia um homem de vanguarda desde os tempos de estudante, sempre à frente de movimentos inovadores.

Como escritor, dono de uma obra seminal em língua portuguesa, certamente teria desfrutado de reconhecimento muito maior se não tivesse optado por permanecer entre as montanhas. Apesar dos insistentes apelos dos amigos para se transferir para o Rio de Janeiro, destino de quase todos os expoentes de sua geração, preferiu ficar em Belo Horizonte. Alegava que não podia por ter "negócios" aqui. Os negócios eram na verdade sua intensa vida interior, o apego às origens, a tudo que fosse genuinamente mineiro, grande insumo de sua obra universal e atemporal. O amor à terra certamente se traduziu, também, na liderança que exerceu, nas iniciativas que patrocinou e no muito que fez pela cultura mineira, não se contentando em ser apenas um grande escritor.

Não reencontrou a fé religiosa perdida na juventude como disse um dia desejar. Era declaradamente agnóstico, mas tinha um sentimento religioso profundo, fascinado pela mitologia do Antigo Testamento, pelo 
fatalismo das profecias. Colecionava oratórios e santos barrocos, tinha a Bíblia na cabeceira e dizia ter muita fé em Nossa Senhora. E foi profundamente cristão em tudo que fez, na simplicidade, na delicadeza de sentimentos, no exercício cotidiano da generosidade.

No final da vida, em função da doença que o acometeu, isolou-se efetivamente e, para nosso desconsolo, parou de produzir, deixando por finalizar muitos contos e duas novelas já esboçadas. Honrou-me com o seu maior legado: a gestão de sua obra e de seu acervo, que doei à Universidade Federal de Minas Gerais, conforme seu desejo. Lá é permanentemente estudado por uma infinidade de pesquisadores dos cinco continentes e cada vez mais reconhecido como um dos grandes nomes da literatura brasileira e latino-americana.

Há 29 anos, no dia 20 setembro de 1991, foi aberta, em Belo Horizonte, a primeira edição do projeto Memória Viva, com uma exposição no Palácio das Artes - "Murilo Rubião, construtor do absurdo" -, toda preparada para homenageá-lo em vida. Não foi possível. Como o grande personagem de si mesmo que sempre foi, o convidado não apareceu. Morrera quatro dias antes. Era uma manhã sombria do dia 16 de setembro, dia do meu aniversário. 